\title{
ПРОДУКТИВНІСТЬ ПОРОСЯТ НА ДОРОЩУВАННІ ЗА ВЕЛИКОГРУПОВОГО УТРИМАННЯ НА ПОЛІМЕРНІЙ ТА БЕТОННІЙ ПІДЛОЗІ
}

Ладика Володимир Іванович доктор сільськогосподарських наук, профресор, академік НААН України Сумський національний аграрний університет ORCID: 0000-0001-6748-7616 E-mail: v.i.ladyka@ukr.net

Хмельничий Леонтій Михайлович доктор сільськогосподарських наук, профресор Сумський національний аграрний університет ORCID: 0000-0001-5175-1291 Email: khmelnychy@ukr.net

Шпетний Микола Борисович кандидат сільськогосподарських наук Сумський національний аграрний університет ORCID: https://orcid.org/0000-0003-4757-5875

E-mail: nshpetny@gmail.com

Вечорка Вікторія Вікторівна кандидат сільськогосподарських наук, доцент Сумський національний аграрний університет ORCID: 0000-0003-4956-2074

E-mail: vvvechorka@gmail.com

В статті вивчалась продуктивність поросят на дорощувані залежно від типу підлоги у різні пори року. Встановлено, що поросята, які утримувались на більш комфортній полімерній підлозі, щодоби споживали більше на 13,8\% комбікорму взимку, на 12,0\% навесні, на 8,2\% влітку та на 7,7\% восени. При великогруповому утриманні поросят в станках 3 частково щілинною полімерною підлогою спостерігались вищі абсолютні прирости взимку - на 18,5\%, навесні - на 10,5\%, влітку - на 11,0\% та восени - на 15,5\%\%. Більш комфортні умови утримання поросят в станках з полімерною підлогою за рахунок вищої інтенсивності росту поросят сприяли зменшенню витрат кормів на одиницю приросту, взимку - на 4,6\%, навесні - на 3,5\%, влітку - на 3,1\% та восени - на 3,9\%. Інтенсивність росту поросят в період їхнього дорощування, в усі пори року, була вищою у станках з полімерною гратчастою підлогою порівняно з тваринами, які вирощувались у цей період на бетонній гратчастій підлозі. В осінньо-зимовий період різниця за інтенсивністю росту поросят при альтернативних типах підлоги зростала, та зменшувалась у весняно-літній період року. Конверсія корму впродовж року більше залежала від пори року, ніж від типу решітчастої підлоги у станку. Збереженість поросят суттєво залежала від типу підлоги і мала значні коливання впродовж року в станках з бетонною решітчастою підлогою, і частка поросят, які загинули в усі пори року також була вищою у цих станках. На основні господарськи корисні ознаки, найвищий вплив чинить тип гратчастої підлоги в станку для дорощування поросят, дещо менший - пора року і найменший, їхня взаємодія. На основі досліджень встановлено недоцільність заміни в станках для дорощування поросят полімерної підлоги на бетонну.

Ключові слова: поросята, дорощування, бетонна підлога, полімерна підлога, сезон року, конверсія корму, жива мaca.

DOI: https://doi.org/10.32845/bsnau.lvst.2019.1-2.1

За повідомленнями авторів [2, 13, 15, 19], створення оптимальних умов утримання у період дорощування поросят сприяє кращій їхній адаптації до нових умов, покращує збереженість, підвищує енергію росту та оплату корму приростами, створює кращі стартові умови на початковому етапі відгодівлі такої досить вразливої технологічної групи. Вони ж засвідчують, що індустріалізація утримання тварин не завжди відповідає їхнім фізіологічним та етологічним потребам і створює дискомфорт для життєздатності $[22,13]$.

За глибоким переконанням Решетника А. О. зі співавторами [13], перспектива виходу української м'ясомолочної продукції на світовий ринок прямо пов'язана з дотримання правил і законів із захисту сільськогосподарських тварин, які діють у Європі та світі, дотриманням їхнього

добробуту, який включає у себе такі поняття як: задоволення фізіологічних, психологічних та соціальних потреб, відповідного оточуючого середовища. При впровадженні в практику вимог добробуту слід виходити з точки зору принципу п'яти свобод: свобода від голоду і спраги, що підтримує добре здоров'я і активність; свобода від дискомфорту (забезпечення відповідного середовища проживання, зручного місця для відпочинку); свобода від болю, травм чи хвороби (превентивні заходи, рання діагностика і лікування); свобода від страху і страждання; свобода реалізації природної поведінки (врахування етології свиней) [5, 12].

У цьому аспекті від конструкції підлоги у свинарнику, особливо в умовах промислових комплексів, залежить гігієна приміщення, комфорт тварин, їхнє здоров'я та показники 
продуктивності $[1,17]$. Основні вимоги до підлогового покриття у свинарнику наступні: підлога має бути досить м'якою, мати добру теплоізоляцію, слабку абразивність, добре чиститись та дезінфікуватися. Разом із тим, вона повинна мати помірну вартість і великий термін експлуатації. Металеві решітки мають бути вкритими 5-міліметровим шаром полівінілхлориду, який збільшує їхню стійкість до корозії та зменшує травматизм поросят [10].

У разі металевої щілинної підлоги для поросят ширина отворів має бути не більша за 9 мм, площа опори - не менша ніж 8 мм, а краще 10-12 мм. Утримання поросят раннього віку на щілинній бетонній підлозі, щілини якої завширшки 13 мм, призводить до типових травм кінцівок. Для великих поросят вагою понад 12 кг вона цілком придатна.

За облаштування щілинної підлоги для свиней ширина планок має бути такою: для відлучених поросят, ремонтного та відгодівельного молодняку - 44-45 мм; для кнурів і маток - 70 мм із просвітом між планками; для кнурів і маток - 26 мм; іншого поголів'я - 20-22 мм. У разі влаштування підлоги з інших матеріалів ширина планок для вказаних груп тварин може бути зменшена до 35-40 мм із просвітом між планками 20 мм. Нормативне навантаження від тварин на

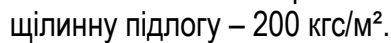

Щілинну підлогу в приміщенні для утримання молодняку на дорощуванні виготовлюють із полівінілхлориду. Підлога характеризується досить високою надійністю й іншими експлуатаційними властивостями: самоочищення від гною, неслизька й тепла поверхня, яка стійка проти дії стічної рідини та дезінфекційних речовин.

У європейських країнах з 2013 року заборонено використання щілинної підлоги на площі станків більше $50 \%$ і в зонах відпочинку свиней на площі більше 10\%. Санкціями є сертифікати на продукцію, які не можливо буде отримати при порушеннях цих законів [8].

Водночас в країнах Північної Америки останнім часом широко використовуються для дорощування поросят метод від відлучення до забою [4], за якого поросят після відлучення утримують на бетонній решітчастій підлозі. Аналогічні тенденції спостерігаються і в деяких європейських країнах. Тоді як в Україні такі технології поки що не набули широкого розповсюдження і є недостатньо вивченими.

Відомо, що одна із проблем промислового свинарства - вплив сезонності на мікроклімат у свинарських приміщеннях і, як наслідок, на їхню продуктивність $[3,6,9,14,16]$.

При дослідженні [18] впливу параметрів мікроклімату в свинарниках, залежно від сезону року на ріст, розвиток і відгодівельні якості молодняку великої білої породи, було встановлено, що найвища температура в приміщеннях при 3-х і 2-х фразних технологіях спостерігалася взимку і становила відповідно 23, 5 і $24,2^{\circ} \mathrm{C}$, відносна вологість - 83,0 і $80,2 \%$ (восени), швидкість руху повітря - 1,01 і 1,0 м/с (влітку), концентрація аміаку - 21,0 і 20,2 мг/м³ (восени) та концентрація вуглекислого газу - 0,32 і 0,25\% (влітку). Перевищення допустимих норм спостерігалось за відносною вологістю, концентрацією аміаку та вуглекислого газу у певні періоди року.
Наступними авторами [11] встановлено більш високу залежність показників мікроклімату від сезонів року в приміщеннях традиційної конструкції, порівняно 3 сучасними приміщеннями. При цьому виявлено вищу продуктивність поросят на дорощуванні у більш комфортних умовах сучасного приміщення.

Виходячи з аналізу літературних джерел, недостатньо вивченим $є$ питання щодо впливу типу підлоги при дорощуванні поросят на їхню продуктивність. Тому, поставлено за мету, з'ясувати особливості впливу різновиду підлоги у станках для дорощування поросят на їхню продуктивність за великогрупового утримання на полімерній та бетонній підло3i.

Матеріали та методи досліджень. В дослідах визначено вплив типу підлоги в станку для дорощування на продуктивність поросят (інтенсивність росту, витрати корму, стан здоров'я і збереженість молодняку) в умовах ТОВ «НВП «Глобинський свинокомплекс» Полтавської області. Для науково-господарського досліду в кожну пору року було сфрормовано за методом груп-аналогів по дві групи поросятвідлученців віком 28 діб у кількості 160 голів кожна, які були поставлені на дорощування в приміщення за однотипної системи підтримання мікроклімату, в станках однакової конструкції на частково щілинній підлозі з розрахунку 0,32 м² на голову.

Утримання поросят контрольної групи відбувалось у станку на частково щілинній полімерній підлозі, а їх аналогів дослідної групи утримували у станках на частково-щілинній бетонній підлозі, з розміром щілин 15 мм. Вентиляція в обох приміщеннях була негативного тиску і підтримувалась автоматично. Обігрів здійснювався за допомогою водяного опалення вмонтованого в суцільну частину підлоги. Місце відпочинку для поросят становило з розрахунку $0,15 \mathrm{~m}^{2}$ на голову.

Годівля поросят обох груп здійснювалась сухими, розсипчастими, повнораціонними комбікормами, вволю 3 кормових автоматів. Облік корму проводився впродовж всього періоду дорощування шляхом завантаження комбікорму вручну при закритих шиберах лінії кормороздачі. Напування поросят піддослідних груп проводилось за допомогою соскових автонапувалок. Видалення гною 3-під решітчастої підлоги станків у приміщеннях здійснювалось за допомогою вакуумно-самопливної системи періодичної дії.

За результатами досліду вивчалось: кількість поросят, які вибули, їх падіж та прирости живої маси при переведенні їх на відгодівлю. На основі цих даних, розраховувались абсолютний, середньодобовий прирости живої маси. По закінченню дослідження було вирахувано середню кількість витраченого комбікорму на одне порося за добу і на 1 кг приросту.

Експериментальні показники опрацьовували за формулами біометричної статистики, наведеними Е. К. Меркурьевой [7].

Результати дослідження, отримані у літню пору року, свідчать, що маса тварин при постановці була досить близькою - 7,99 кг в контрольній групі та 7,85 кг - у дослідній (табл. 1). 
Інтенсивність росту, витрати корму поросятами за утримання

в станках за різного типу підлоги (влітку), $\bar{X} \pm S_{\bar{X}}$

\begin{tabular}{|l|c|c|}
\hline \multicolumn{1}{|c|}{ Показник } & Контрольна група (полімерна підлога) & Дослідна група (бетонна підлога) \\
\hline Жива маса при постановці, кг & $7,99 \pm 0,05$ & $7,85 \pm 0,06$ \\
\hline Тривалість дорощування, діб & 51,0 & 51,0 \\
\hline Маса при закінченні дорощування, кг & $31,19 \pm 0,72$ & $28,50 \pm 0,92^{\text {** }}$ \\
\hline Абсолютний приріст, кг & $23,20 \pm 0,68$ & $429 \pm 10,3^{*}$ \\
\hline Середньодобовий приріст, г & $455 \pm 7,6$ & 113,6 \\
\hline Відносний приріст, \% & 118,4 & 0,78 \\
\hline Добове споживання корму, кг/гол & 0,85 & 1,93 \\
\hline Конверсія корму, кг & 1,87 & 2,26 \\
\hline Витрати корму, корм. од. & 2,19 & \\
\hline
\end{tabular}

Тип підлоги в станках для утримання поросят під час їх дорощування мав суттєвий вплив на інтенсивність росту. Так, по закінченню дорощування ця різниця в живій масі вірогідно склала 2,69 кг або 8,6\% (P<0,01) на користь поросят контрольної групи, які утримувались в станках з полімерною підлогою. Вищим у них виявився і абсолютний приріст, який за 51 добу дорощування склав 23,20 кг, тоді як у тварин дослідної групи, які утримувались на бетонній перфорованій підлозі, тільки 20,65 кг, що на 2,55 кг або 11,0\% менше $(\mathrm{P}<0,01)$, ніж у поросят контрольної групи.

Щодоби поросята контрольної групи приростали на 455 г, тоді як їх аналоги дослідної групи мали середньодобовий приріст на 26 г або 5,7\% (P<0,05) нижчий.

Відносний приріст поросят дослідної групи за умов їх утримання на бетонній щілинній підлозі виявився на 4,8\% нижчим порівняно з тваринами, які утримувались в станках на полімерній підлозі.

Умови утримання поросят вплинули на їх апетит i, відповідно, на кількість спожитого корму. Так, поросята, які утримувались на більш комфортній полімерній підлозі, щодоби споживали - 0,85 кг комбікорму, тоді як їх аналоги 3 дослідної групи в станках для утримання яких використовували бетонну щілинну підлогу тільки - 0,78 кг.

Більш комфортні умови утримання в станках з полімерною підлогою за рахунок вищої інтенсивності росту поросят сприяли зменшенню витрат кормів на одиницю приросту, так на 1 кг приросту тварини контрольної групи витрачали 1,87 кг комбікорму, що склало 2,19 корм. од., тоді як їх ровесники 3 дослідної - 1,93 кг або 2,26 корм. од.

Тип підлоги в станках для утримання поросят вплинув і на стан захворюваності поросят та відсоток їх вибуття та загибелі (рис. 1). Наведені на рис. 1 показники свідчать, що позапланової ветеринарної допомоги було надано 6,4\% тваринам контрольної групи, які утримувались на полімерній підлозі, у той час як 17,3\% їх аналогів з дослідної, які утримувались на бетонній підлозі, потребували позапланового ветеринарного втручання.

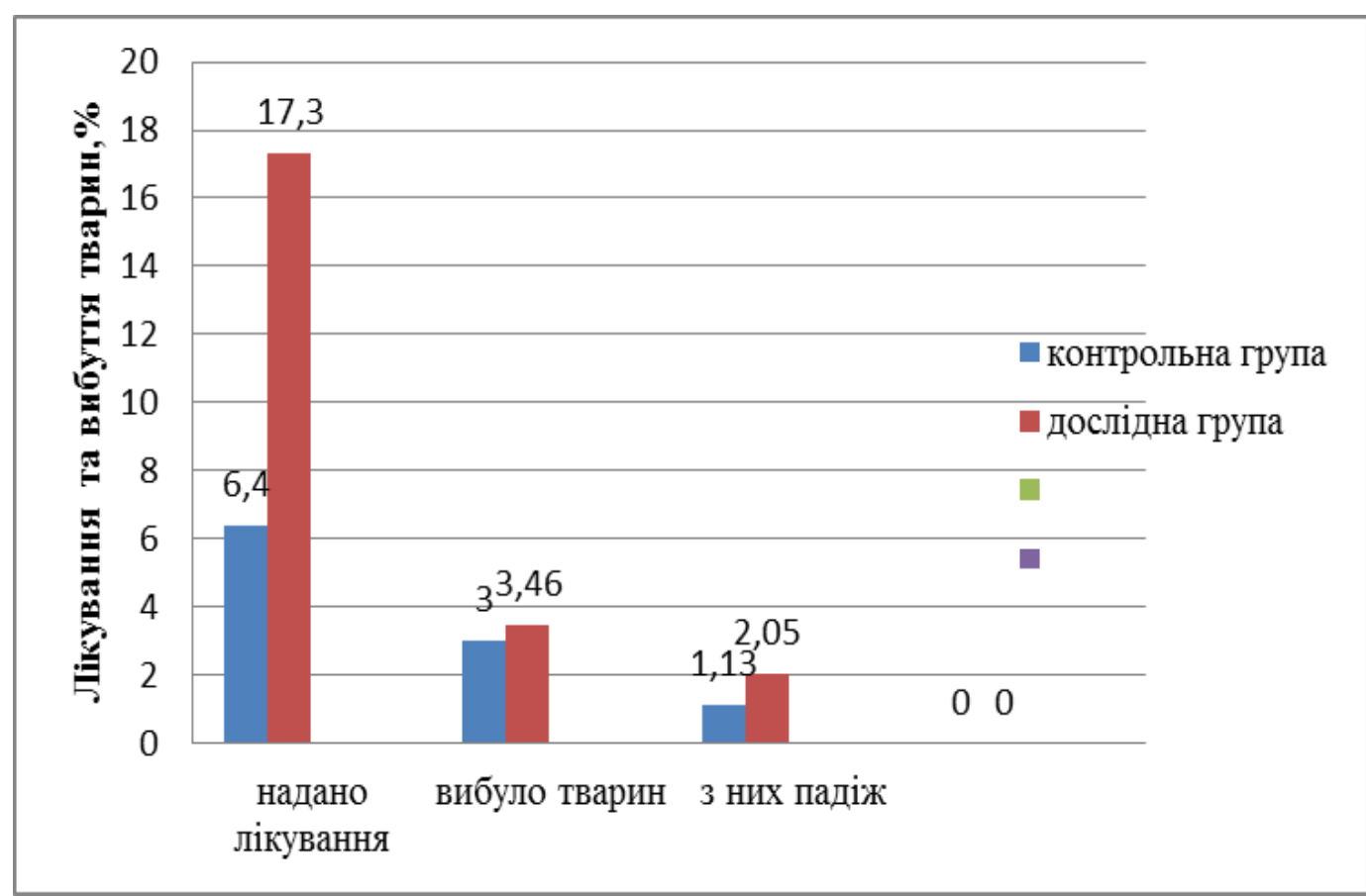

Рис. 1. Частка тварин, яка потребувала лікування та відсоток їх вибуття

Вищою в дослідній групі виявилась і частка втрат поголів'я за час дорощування, яка склала $3,46 \%$ проти 3,00\% в контрольній.
Відсоток загибелі тварин виявився також вищим серед поросят дослідної групи 2,05\% проти 1,13\% - в контрольній. 
Восени, як і влітку суттєвої різниці у середньої маси тварин при постановці не спостерігалось (табл. 2).

Водночас за 51 добу відгодівлі тварини контрольної групи приросли на 24,08 кг, тоді як їх аналоги з дослідної групи мали абсолютний приріст за цей період вірогідно менше на 3,73 кг $(P<0,001)$. Це спричинило і різну масу тварин по завершуванні дорощування. Так, поросята контрольної групи, які утримувались на полімерній решітчастій підлозі мали масу по завершенню періоду дорощування вірогідно вищу на 3,79 кг ( $\mathrm{P}<0,001)$.

Тварини, які утримувались в станках з полімерною підлогою виявили вищу інтенсивність росту. Щодоби вони приростали в середньому на 472 г, в той час як їх аналоги з дослідної групи мали середньодобові прирости за цей же період вірогідно нижчі на 73 г (Р<0,001). Відносний приріст також виявився вищим на 7,8\% порівняно з тваринами, які утримувались на бетонній перфорованій підлозі.

Інтенсивність росту, витрати корму поросятами за утримання

Таблиця 2 в станках з різним типом підлоги (восени), $\bar{X} \pm S_{\bar{X}}$

\begin{tabular}{|l|c|c|}
\hline \multicolumn{1}{|c|}{ Показник } & Контрольна група (полімерна підлога) & Дослідна група (бетонна підлога) \\
\hline Жива маса при постановці, кг & $8,04 \pm 0,05$ & $7,98 \pm 0,03$ \\
\hline Жива маса при закінченні дорощування, кг & $32,12 \pm 0,66$ & $28,33 \pm 0,92$ \\
\hline Абсолютний приріст, кг & $24,08 \pm 0,58$ & $20,35 \pm 0,77^{* * *}$ \\
\hline Середньодобовий приріст, г & $472 \pm 8,3$ & $399 \pm 12,1^{* * *}$ \\
\hline Відносний приріст, \% & 119,9 & 112,1 \\
\hline Добове споживання корму, кг/гол & 0,83 & 0,73 \\
\hline Конверсія корму, кг & 1,76 & 1,83 \\
\hline Витрати корму, корм. од. & 2,06 & 2,14 \\
\hline
\end{tabular}

Більш комфортні умови утримання поросят контрольної групи спричинили підвищений їх апетит, так щодоби вони споживали на 0,1 кг більше корму, що посприяло вищій їх енергії росту, що, в свою чергу, призвело до вищої на 0,07 кг, або 0,08 корм. од. конверсії корму.

Як і в літній період, восени більшій кількості поросят дослідної групи знадобилося ветеринарна допомога. Так, $21,2 \%$ поросят дослідної групи потребували ветеринарної допомоги, тоді як їх аналогам, які утримувались на полімерній підлозі така допомога надавалася $-8,3 \%$. Умови утримання вплинули на кількість тварин що вибули. Так, за період дорощування в контрольній групі вибуло - 2,8\% поросят, тоді як в дослідній 5,1\%. Меншим у тварин контрольної групи був і відсоток загиблих поросят, який склав 1,9\%, тоді як в дослідній він склав 2,8\%.

Отже, тип підлоги в станку при утриманні поросят на дорощуванні в осінній період мав суттєвий вплив на споживання корму і як наслідок на інтенсивність росту поросят, і відповідно на абсолютний приріст, й кінцеву масу поросят при дорощуванні.

При дослідженні залежності господарськи корисних ознак при дорощуванні поросят за утриманні їх в станках 3 різним типом підлоги в більш жорстких умовах зимової пори року встановлено, що тварини, які утримувались в станках 3 полімерною підлогою щодоби споживали на 0,12 кг більше корму в розрахунку на одну голову і, як наслідок, більш інтенсивно росли (табл. 3).

Інтенсивність росту, витрати корму поросятами за утримання в станках з різним типом підлоги (взимку),

Таблиця 3

$$
\bar{X} \pm S_{\bar{X}}
$$

\begin{tabular}{|l|c|c|}
\hline \multicolumn{1}{|c|}{ Показник } & Контрольна група (полімерна підлога) & Дослідна група (бетонна підлога) \\
\hline Жива маса при постановці, кг & $7,49 \pm 0,08$ & $7,54 \pm 0,07$ \\
\hline Жива маса при закінченні дорощування, кг & $31,33 \pm 0,44$ & $26,98 \pm 1,16^{* * *}$ \\
\hline Абсолютний приріст, кг & $23,84 \pm 0,45$ & $19,44 \pm 1,08^{* * *}$ \\
\hline Середньодобовий приріст, г & $467 \pm 6,2$ & $381 \pm 14,6^{* * *}$ \\
\hline Відносний приріст, \% & 122,8 & 112,6 \\
\hline Добове споживання корму, кг/гол & 0,87 & 0,75 \\
\hline Конверсія корму, кг & 1,85 & 1,96 \\
\hline Витрати корму, корм. од. & 2,16 & 2,26 \\
\hline
\end{tabular}

3 показників таблиці 3 витікає, що більш комфортні умови утримання в екстремальний зимовий період сприяли вищому на 86 г $(\mathrm{P}<0,001)$ середньодобовому приросту. Як наслідок у тварин цієї групи був вищим на 10,2\% відносний приріст та на 4,4 кг ( $<<0,001)$ абсолютний приріст. В результаті цього по закінченню періоду дорощування підсвинки контрольної групи мали вищу на 4,35 кг (P<0,001) індивідуальну масу.

Підвищений апетит, спричинений кращими умовами утримання, який спричинив підвищену інтенсивність росту сприяв поліпшенню на 0,11 кг, або на 0,13 корм. од конверсії корму.

В жорстких умовах зимового періоду майже третині поросят дослідної групи було надано ветеринарну допомогу, тоді як поросятам, які утримувались на полімерній підлозі така допомога знадобилась в 12,3\%.

Відповідно зросла на 5,9\% частка вибуття тварин, які утримувались в станках з бетонною перфорованою підлогою. Також зросла на 2,1\% частка загиблих тварин.

Таким чином, у зимовий період тип підлоги в станку суттєво вплинув на інтенсивність росту поросят, конверсію корму та частку тварин, які вибули і загинули. 
3 настанням більш сприятливих умов зовнішнього середовища, навесні спостерігалося зменшення різниці в продуктивності тварин, які утримувались в станках з різним типом підлоги. Як і в попередні періоди року суттєвої різниці між масою тварин при постановці на дорощування контрольної та дослідної груп не спостерігалось (табл. 4). Тоді як, при переведенні на відгодівлю вона склала 2,43 кг (P<0,01). Цей факт спричинений вищою інтенсивністю росту поросят контрольної групи, які щодоби приростали на 49 г більше i, як наслідок, мали на 2,49 кг вищий абсолютний приріст і на $6,1 \%$ відносний.

Щодоби поросята, які утримувались в станках з бе- тонною полімерною підлогою споживали на 0,06 кг корму менше і мали гіршу на 0,06 кг, або 0,07 корм. од. конверсію корму.

Покращення умов зовнішнього середовища зменшило частку тварин, які потребували ветеринарної допомоги до $16,2 \%$ в дослідній групі і 8,3\% - в контрольній. Також навесні зменшилась кількість вибулих тварин в дослідній групі до 7,9\%, тоді як в контрольній - вона підвищилась до 3,8\%. Частка загиблих тварин в дослідній групі зменшилась порівняно із зимовим періодом та склала 3,5\%. Водночас в контрольній групі вона підвищилась в порівнянні із зимовим періодом та склала 2,3\%.

Таблиця 4

Інтенсивність росту, витрати корму поросятами за утримання в станках з різним типом підлоги (навесні), $\bar{X} \pm S_{\bar{X}}$

\begin{tabular}{|l|c|c|}
\hline \multicolumn{1}{|c|}{ Показник } & Контрольна група (полімерна підлога) & Дослідна група (бетонна підлога) \\
\hline Жива маса при постановці, кг & $8,05 \pm 0,09$ & $8,11 \pm 0,11$ \\
\hline Жива маса при закінченні дорощування, кг & $30,99 \pm 0,51$ & $28,56 \pm 0,66^{* *}$ \\
\hline Абсолютний приріст, кг & $22,94 \pm 0,47$ & $20,45 \pm 0,63^{* *}$ \\
\hline Середньодобовий приріст, г & $450 \pm 8,31$ & $401 \pm 8,11^{* *}$ \\
\hline Відносний приріст, \% & 117,6 & 111,5 \\
\hline Добове споживання корму, кг/гол & 0,78 & 0,72 \\
\hline Конверсія корму, кг & 1,73 & 1,79 \\
\hline Витрати корму, корм. од. & 2,02 & 2,09 \\
\hline
\end{tabular}

Таким чином, і у весняний період, як і в інші пори року, продуктивність тварин суттєво залежала від типу підлоги у станку. Тварини, які утримувались в станках з полімерною перфорованою підлогою споживали щодоби більше корму, більш інтенсивно росли, краще оплачували корм приростами та мали суттєво вищу масу при переведенні на відгодівлю. Стан здоров'я та збереженість поросят також був кращим у станках з полімерною підлогою в порівнянні з бетон- ною.

При співставленні динаміки продуктивних показників поросят, які дорощувались в станках з різним типом підлоги впродовж чотирьох пір року, встановлено, що інтенсивність росту поросят залежала від пори року, так різниця в середньодобових приростах влітку між тваринами контрольної та дослідної групи склала 26 г (рис. 2).

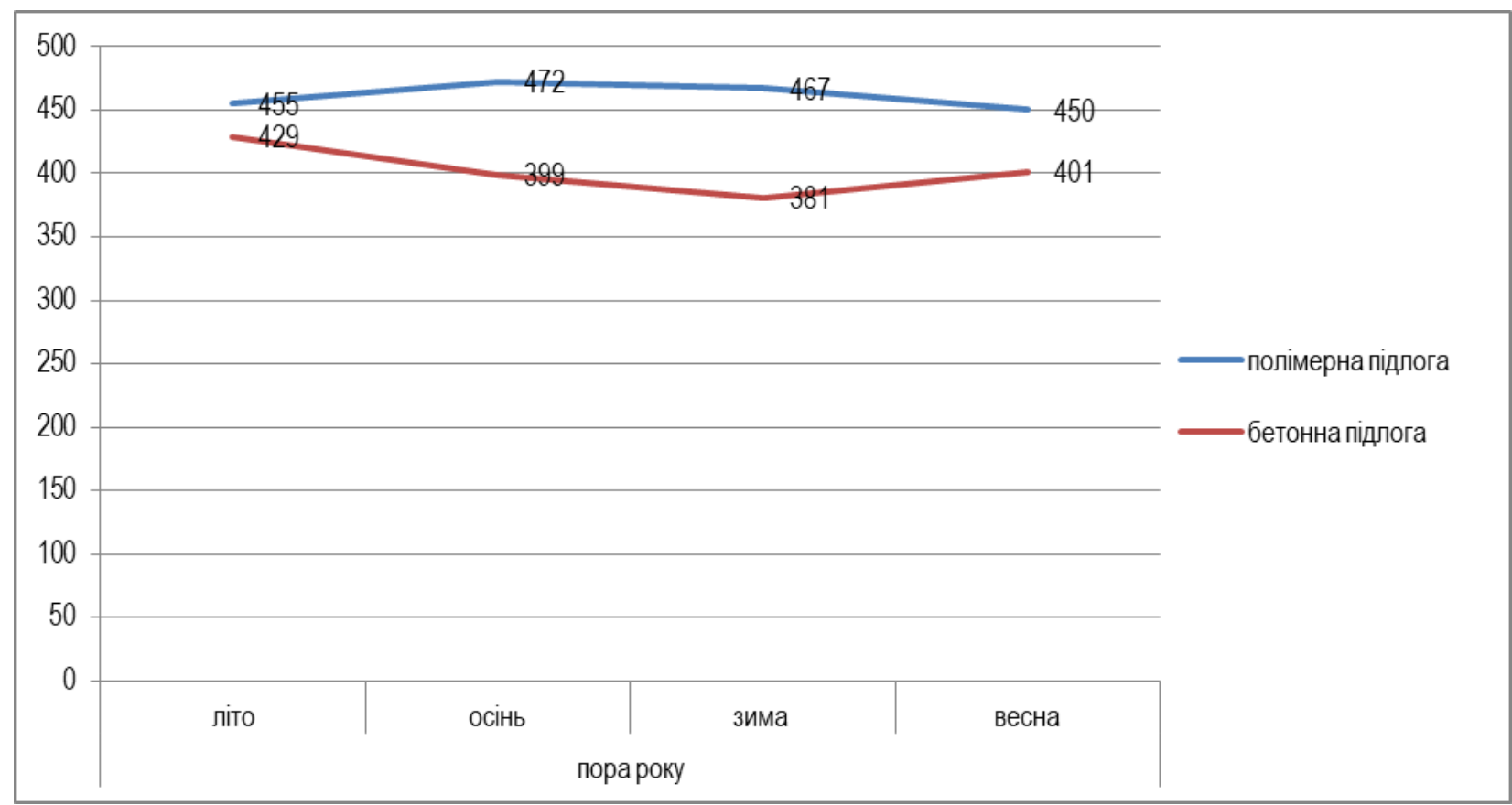

Рис. 2. Сезонна динаміка середньодобових приростів поросят на дорощуванні за різних типів підлоги в станку, г

Із зменшенням впливу високих температур на продуктивні показники, середньодобові прирости поросят, які утримувались на полімерній підлозі зросли на 17 г. Водночас у тварин, які утримувались на бетонній підлозі вони Вісник Сумського національного аграрного університету Серія «Тваринництво», випуск 1-2 (36-37), 2019 восени знизились на 30 г і різниця між тваринами контрольної та дослідної групи, восени склала 73 г (Р<0,001).

Високі середньодобові прирости у тварин контрольної групи збереглися і в зимовий період, в той час як у тва- 
рин дослідної групи вони знову знизились на 18 г, і різниця між контрольною та дослідною групою сягнула 86 г $(\mathrm{P}<0,001)$. Навесні прирости тварин, які утримувались на полімерній підлозі знизились порівняно із зимовим періодом на 17 г, тоді як у їх аналогів, які утримувались на бетонній перфорованій підлозі вони зросли на 20 г, але тварини контрольної групи і в цю пору року перевершували аналогів дослідної групи на 49 г.

Отже, інтенсивність росту поросят в період їх доро- щування в усі пори року була вищою в станках з полімерною гратчастою підлогою порівняно з тваринами, які вирощувались в цей період на бетонній гратчастій підлозі. В осінньозимовий період різниця в середньодобових поросят за альтернативних типів підлоги зростала, та зменшувалась у весняно-ліній період року.

Комфортність умов утримання, спричинена типом підлоги в станку вплинула на кількість спожитого корму тваринами (рис. 3).

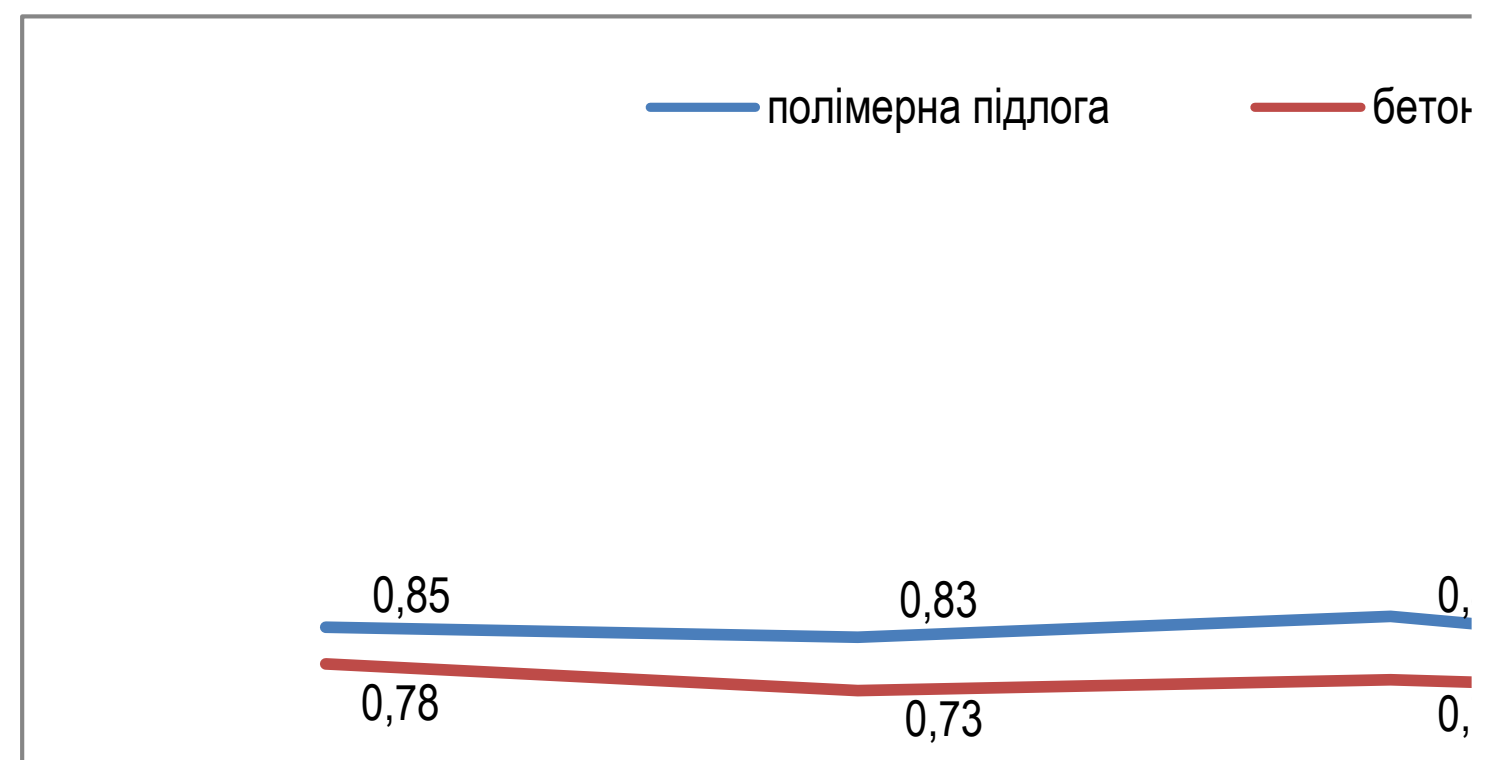

Рис. 3. Сезонна динаміка споживання корму поросятами на дорощуванні за різних типів підлоги в станку, кг

У всі періоди року тварини контрольної групи споживали 0,78-0,87 кг корму на одну голову за добу і цей показник у них майже не залежав від пори року. За умов утримання в станках з бетонною підлогою тварини споживали 0,720,78 кг корму на одну голову за добу. Вищими ці показники були влітку та взимку, а нижчими у перехідні пори року.

Таким чином, споживання корму підвищувалось в екстремальні пори року і знижувалось в перехідні. Тварини в більш комфортних умовах станків з полімерною підлогою в усі пори року споживали щодоби корму більше ніж їх аналог з дослідної групи.

Інтенсивність росту поросят спричинила і різницю в абсолютних приростах, які також залежали від пори року (рис. 4). 


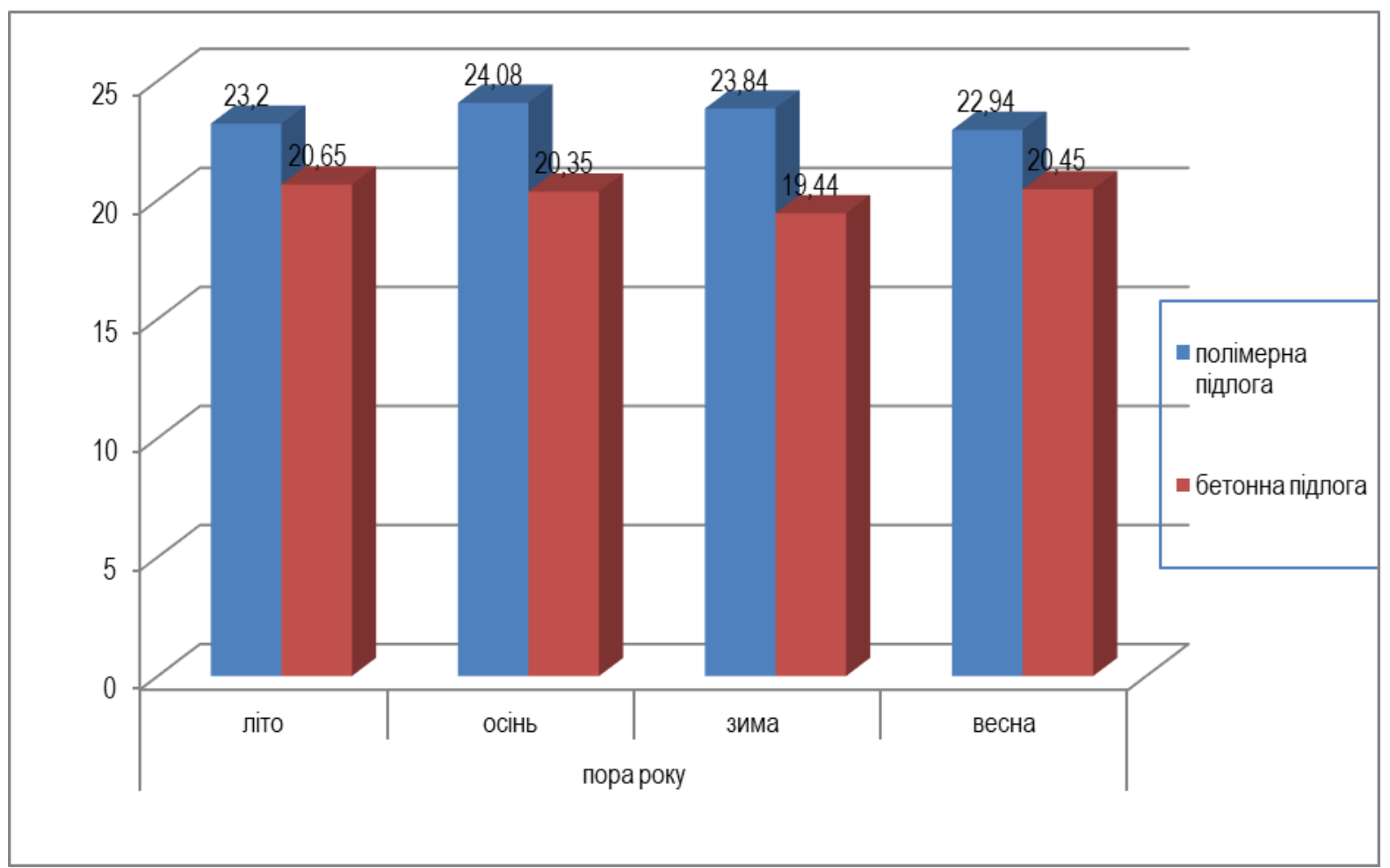

Рис. 4. Сезонна динаміка абсолютних приростів поросят на дорощуванні за різних типів підлоги в станку, кг

У тварин контрольної групи найвищі абсолютні прирости були в осінній період з поступовим їх зниженням взимку - на 0,24 кг, влітку - на 0,88 кг і навесні - на 1,14 кг. Тобто пора року мала суттєвий вплив на абсолютний приріст за умов утримання в станках з полімерною підлогою.

В станках з альтернативним типом підлоги найвищий абсолютний приріст виявлено у тварин влітку. Восени він знизився на 0,3 кг, взимку - на 1,21 кг та навесні - на 0,25 кг, в порівнянні з літнім періодом. Отже, абсолютний приріст свиней залежав від пори року та змінювався впродовж року неоднаково в станках з різним типом підлоги.

Витрати корму на один кілограм приросту також залежали від сезону року і найвищими вони були у тварин, які утримувались в станках за обох типів підлог у зимовий період та влітку, тоді як в перехідні пори року конверсія корму покращувалась у тварин в обох типах станків (рис. 5).

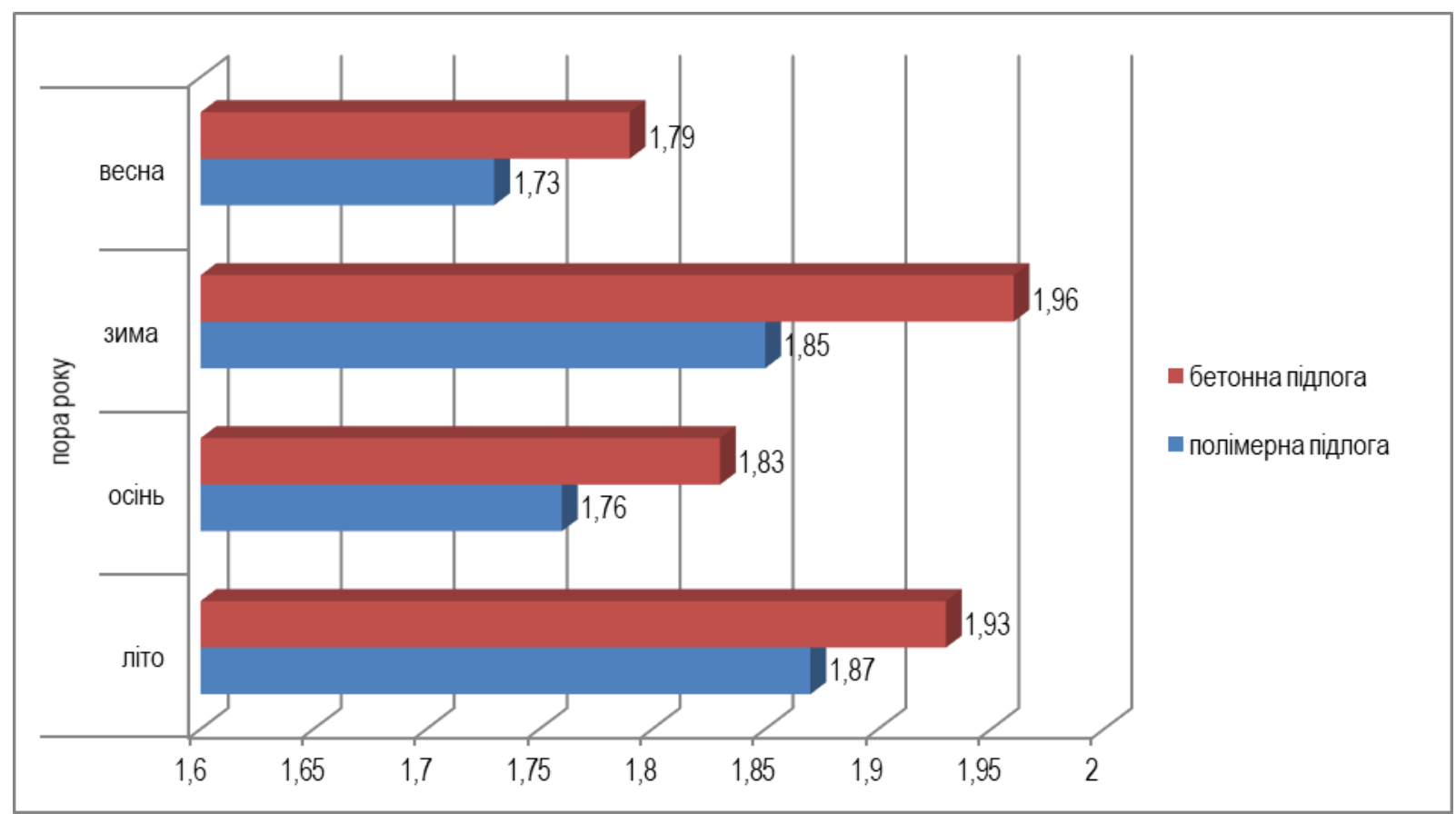

Рис. 5. Сезонна динаміка конверсії корму поросятами на дорощуванні за різних типів підлоги в станку, кг

В контрольній групі нижча конверсія корму тваринами виявилась навесні - 1,73 кг. Восени вона збільшилась на 0,03 кг, взимку - на 0,12 кг та влітку - на 0,14 кг порівняно з весняним періодом. В станках з бетонною перфорованою підлогою конверсія корму виявилась також найкращою навесні - 1,79 кг. Тоді як, восени вона була 0,04 кг гіршою,

Вісник Сумського національного аграрного університету 
взимку - на 0,17 кг, влітку - на 0,14 кг в порівнянні з весняним періодом.

Таким чином, конверсії корму впродовж року більше залежала від пори року ніж від типу решітчастої підлоги в станку для дорощування поросят.

Тип підлоги в станку суттєво вплинув на відхід поро- сят (рис. 6). Так, у тварин дослідної групи він знаходився у межах 2,7-4,6\% і найменшим він був у осінній період, а найвищим навесні. У тварин дослідної групи відхід поросят коливався у межах 3,46-9,3\% і найвищим він був взимку та найнижчим влітку.

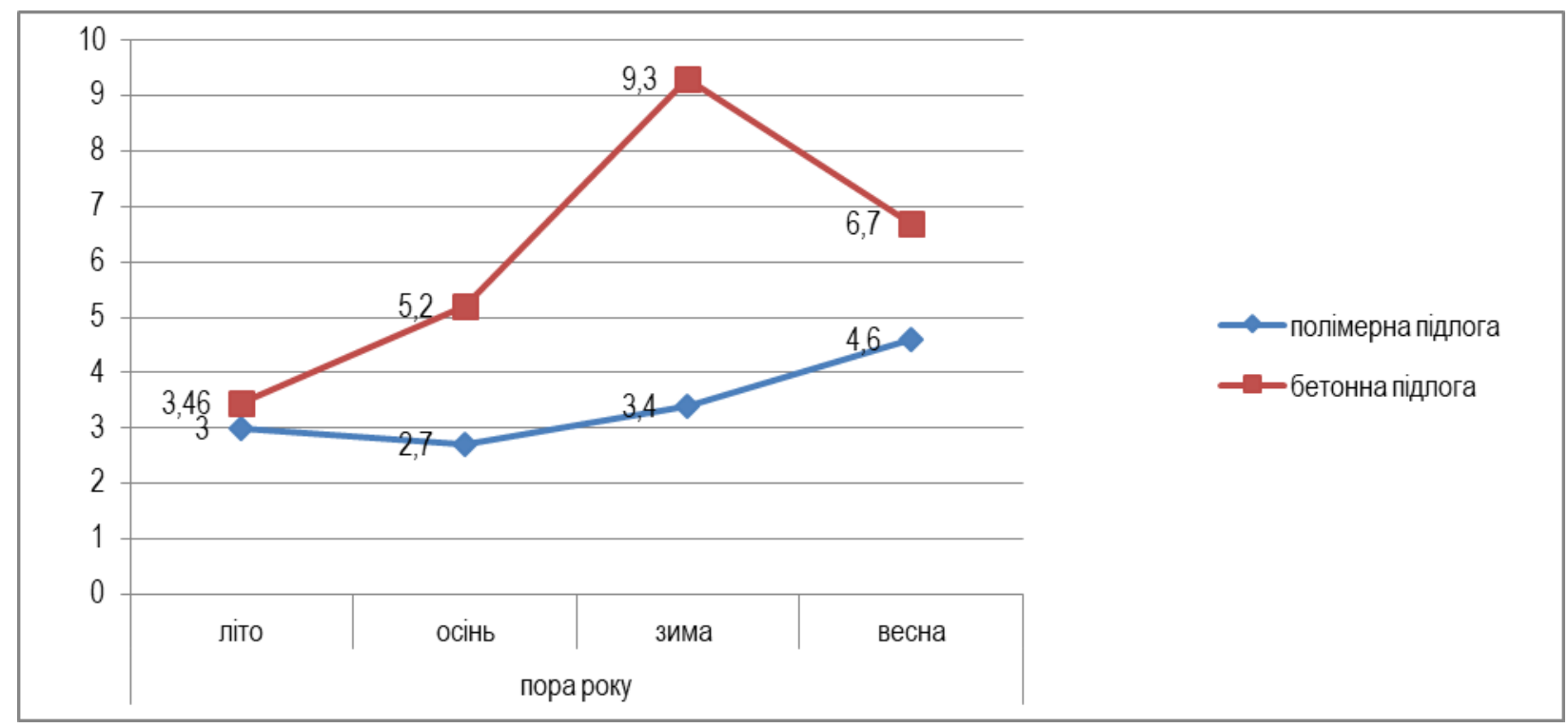

Рис. 6. Сезонна динаміка технологічного відходу поросят на дорощуванні за різних типів підлоги в станку, \%

Різниця в технологічному відході поросят між контрольною та дослідною групою влітку склала 0,46\%, тоді як взимку сягала 5,9\%, в осінній період вона становила 2,5\%, а на весні 2,1\% на користь контрольної групи.

Отже, збереженість поросят суттєво залежала від типу підлоги і мала значні коливання впродовж року в станках з бетонною решітчастою підлогою.

Загибель поросят під час дорощування також змінювалась впродовж року (рис. 7). Найнижчою за обох типів підлоги вона виявилась влітку. Восени вона зросла в обох типах станків. Тоді як, взимку в станках з полімерною підло- гою вона знизилась на 0,16\%, а за альтернативної підлоги зросла на 1,2\%, що пояснюється негативним впливом високої теплопровідності бетонної перфорованої підлоги на здоров'я поросят. У весняну пору року частка поросят, які загинули склала 2,3\% в станках 3 полімерною підлогою і 3,5\% в станках з бетонною підлогою.

Таким чином, частка поросят, які загинули в усі пори року була вищою в станках з бетонною перфорованою підлогою. Різниця в кількості загиблих поросят між станками 3 альтернативними типами підлоги склала влітку - 0,9\%, восени $-0,7 \%$, взимку $-1,8 \%$ та навесні - $1,2 \%$.

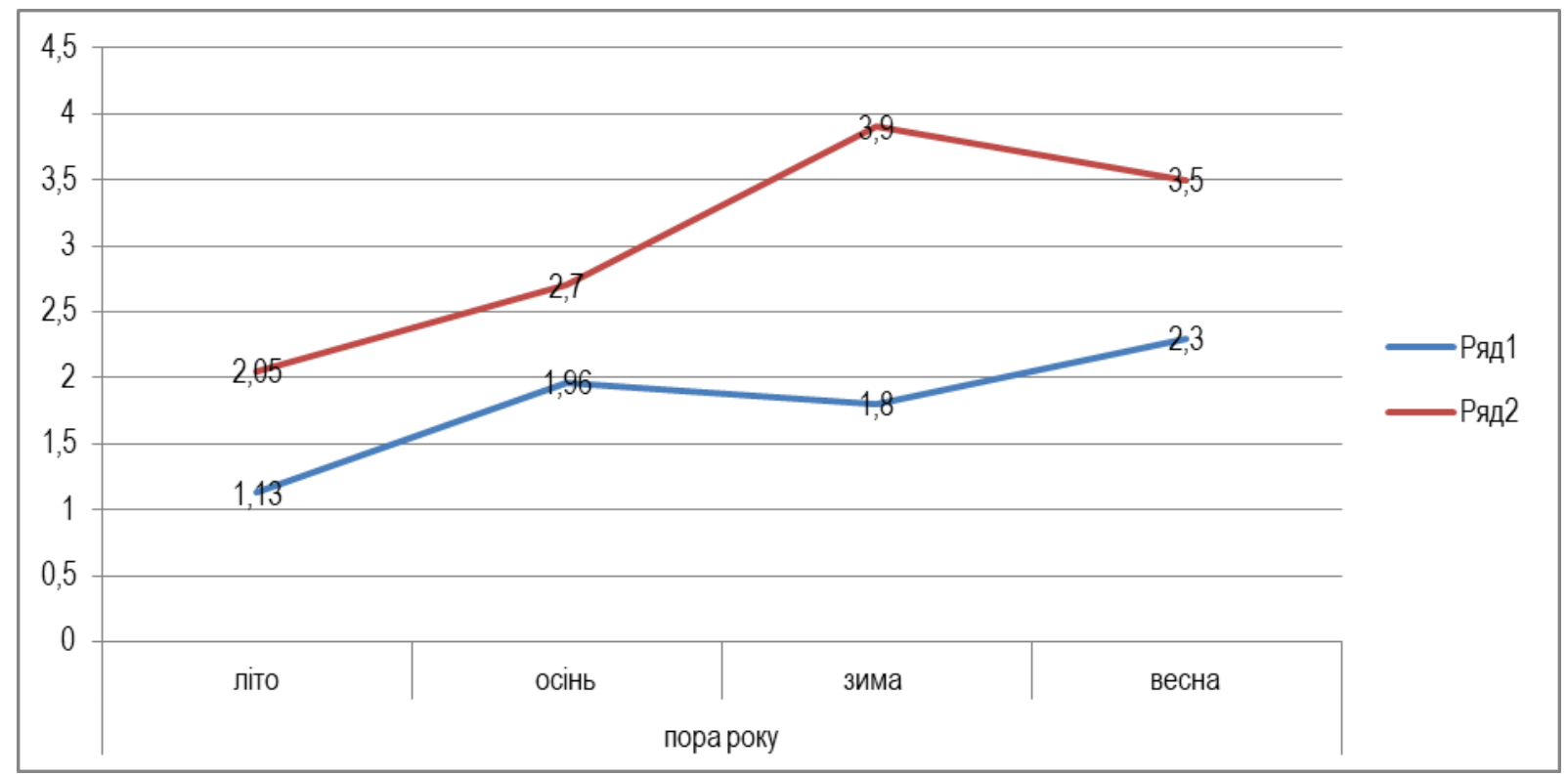

Рис. 7. Сезонна динаміка загибелі поросят на дорощуванні за різних типів підлоги в станку, \% 
За результатами дослідження було проведено двофакторний дисперсійний аналіз, результати якого наведено

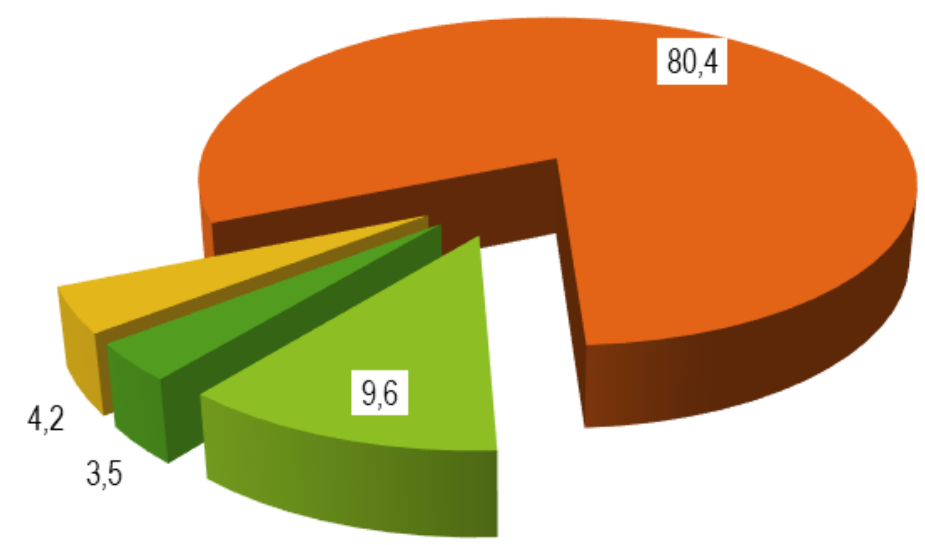

Рис. 8. Вплив типу підлоги та пори року на середньодобові прирости, \%

3 діаграми видно, що частка неврахованих факторів, які вплинули на середньодобові прирости склала 80,4\%. Високий вірогідний вплив $(\mathrm{P}<0,01)$ на цей показник мав тип підлоги, значно нижчий - пора року. Взаємодія факторів склала $4,2 \%$.
При визначенні впливу факторів, що вивчалися на конверсію корму (рис. 9), встановлено високий вірогідний вплив на цей показник типу підлоги $9,7 \%(P<0,05)$, тоді як сезон року впливав на конверсію корму на 3,9\%, а взаємодія цих фракторів тільки на 2,9\%.
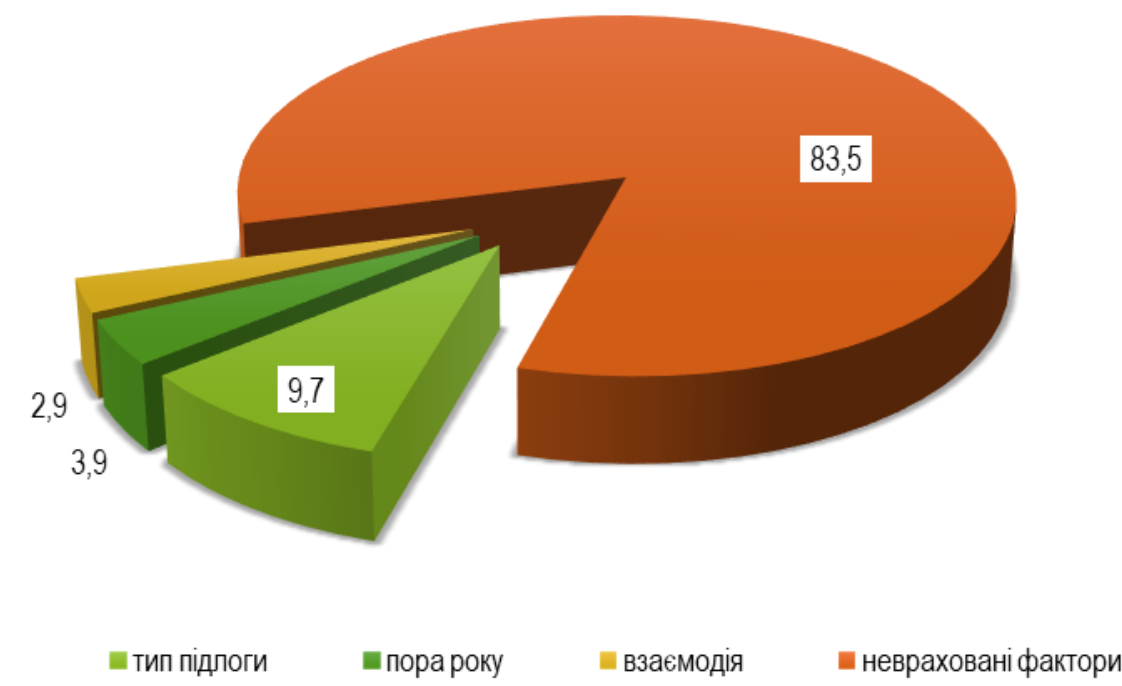

Рис. 9. Вплив факторів типу підлоги та пори року на конверсію корму \%

Збереженість поросят також нерівномірно залежала від факторів, що вивчаються, найвищий вплив на цей показник мав тип підлоги - 13,6\% ( $<<0,001)$, тоді як пора року мала $5,6 \%$ впливу $(P<0,05)$, а взаємодія факторів - 4,9\%. Невраховані фрактори мали силу впливу - 75,9\% (рис. 10).
Таким чином, на основні господарськи корисних ознак, значно вищим виявився вплив типу ґратчастої підлоги в станку для дорощування поросят - 9,7-13,6\%. Тоді як пора року впливала на ці ж ознаки на 3,5-5,6\%, а їх взаємодія на $2,9-4,9 \%$. 


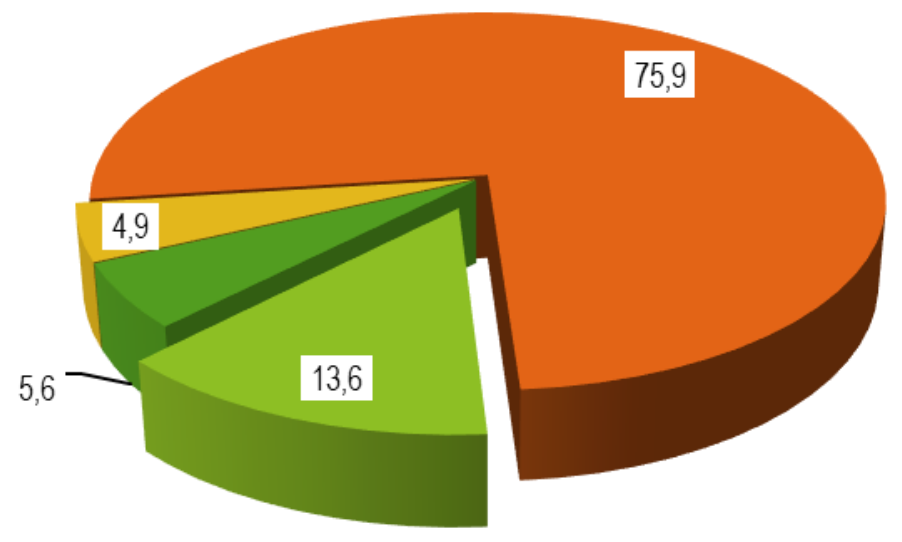

Рис. 10. Вплив факторів типу підлоги та пори року на збереженість, \%

Висновки. 1. Інтенсивність росту поросят в період їх дорощування в усі пори року була вищою в станках з полімерною іратчастою підлогою порівняно з тваринами, які вирощувались в цей період на бетонній ґратчастій підлозі.

2. В осінньо-зимовий період різниця в середньодобових приростах поросят за альтернативних типів підлоги зростала, та зменшувалась у весняно-літній період року. Абсолютний приріст свиней залежав від пори року та змінювався впродовж року неоднаково в станках з різним типом підлоги.

3. Конверсія корму впродовж року більше залежала від його пори, ніж від типу решітчастої підлоги в станку для дорощування поросят.

4. Збереженість поросят суттєво залежала від типу підлоги і мала значні коливання впродовж року в станках з бетонною решітчастою підлогою. Частка поросят, які загинули в усі пори року, також була вищою у цих станках.

6. На основні господарськи корисні ознаки найвищий вплив чинить тип ґратчастої підлоги у станку для дорощування поросят, дещо менше пора року і найменше їх взаємодія.

7. На основі експериментальних досліджень встановлено недоцільність заміни в станках для дорощування поросят полімерної підлоги на бетонну.

\section{Список використаної літератури:}

1. Баньковська І.Б. Вплив фракторів генотипу та типу підлоги на масу туш і внутрішніх органів свиней // Науковотехнічний бюлетень IT HАAН. 2014. № 112. С. 11-17.

2. Бугаєвський В.М., Остапенко О.М., Данильчук М.І. Вплив середовища та технології утримання на продуктивність Свиней. Наукові праці МДГУ. 2010. Вип. 119. Т. 132. С. 59-61.

3. Демчук М.В., Решетнік А.О. Мікроклімат та ефективність роботи системи вентиляції в реконструйованих приміщеннях для свиней в різні періоди року. Наук. вісн. ЛНАВМ. Львів, 2006. Т. 8. № 1 (28). С. 36-42.

4. Еріксон Д. Американська технологія утримання свиней (від відлучення до забою). Прибуткове свинарство. 2015. № 3 (27). C. 64-67.

5. Кремпа Н.Ю., Демчук М.В. Порівняльна добробутна оцінка сучасних інтенсивних технологій виробництва та систем утримання тварин. Науковий вісник ЛНУВМБТ імені С.3. Ґжицького. 2012. Т. 14. № 3 (53). Ч. 2. С. 347-352.

6. Кузнецов А.Ф. Микроклимат помещений и естественная резистентность организма откармливаемых свиней в зависимости от сезона года. Гигиена промышленного животноводства. Новочеркасск, 1978.С. 140-141.

7. Меркурьева Е.К. Генетические основы селекции в скотоводстве / Е. К. Меркурьева. М. : Колос, 1977. 240 с.

8. Найденко В.К. Совершенствование технологий на свинофрермах и свинокомплексах. Перспективное свиноводство: теория и практика. 2011. № 2. С. 6.

9. Петрушко А.С., Ходосовский Д.Н., Рудаковская И.И. [и др.] Откормочные и мясосальные качества свиней при различных условиях содержания. Вісник аграрної науки Причорномор'я. 2015. Вип. 2 (2). С. 55-62.

10. Писарев Ю.Н. Серебряков С. ІА. Современные системы содержания свиней. Свиноводство промышленное и племенное. 2008. № 1. С. 25-27.

11. Повод М.Г., Крамар Н.І. Відгодівельні якості поросят на дорощуванні залежно від умов їх утримання в різні періоди року. Вісник Сумського НАУ. 2013. № 7. С. 173-178.

12. Демчук М.В., Решетник А.О., Банас Т.В. [та ін.] Порівняльна добробутна оцінка сучасних інтенсивних технологій виробництва свиней. Науковий вісник ЛНУВМБТ ім. С. 3. Ґжицького. 2006. Т. 8. № 2 (29). С. 48-55.

13. Решетник А.О., Смоляк В.В., Лайтер-Москалюк С.В. Стан добробуту свиней у промисловому свинарстві. Науковий вісник ЛНУВМБТ ім. С. 3. Ґжицького. 2016. Т. 18. № 4 (72). С. 66-71.

14. Сабельникова Ю.К., Попова О.А. Влияние сезонов года на микроклимат помещения для свиней. Молодёжный аграрный форум 2018 : матер. междунар. студенческой научной конференции. 2018. С. 199.

15. Садомов Н.А. Энергия роста поросят на доращивании в зависимости от способа содержания. Актуальные про- 
блемы интенсивного развития животноводства : материалы XVIII Междунар. науч.-практ. конф., посвященной 85-летию зооинженерного факультета и 175-летию УО «Белорусская государственная сельскохозяйственная академия» (г. Горки, 2829 мая 2015 г.). С. 163-166.

16. Стародубець О.О. Вплив сезону року на відтворювальні якості свиноматок. Вісник аграрної науки Причорномор'я. 2015. Вип. 4. Т. 2. С. 100-103.

17. Хаммер К. Содержание свиней с подстилкой и без неё. Немецкое птицеводство и свиноводство. 1991. 183 с.

18. Чернова С. Е., Казаков В.С. Влияние микроклимата в помещении на рост, развитие и откормочные качества молодняка свиней. Известия ОГАУ. 2014. № 6 (50). С. 127-129.

19. Чёрный Н.В., Онокиенко Н.И., Момот Л.Н. Влияние полов на здоровье свиней. Пути интенсификации отрасли свиноводства в странах СНГ : тез. докл. ХІІІ междунар. науч.-практ. конф. Жодино, 2006. С. 162-163.

\section{References:}

1. Bankovska, I.B. Vplyv faktoriv henotypu ta typu pidlohy na masu tush i vnutrishnikh orhaniv svyney [Influence of genotype factors and type of floor on the mass of carcasses and internal organs of pigs]. Naukovo-tekhnichnyy byuleten' IT NAAN [Scientific and Technical Bulletin of IT NAAN], 2014, no. 112, pp. 11-17.

2. Buhayevskyi, V.M., Ostapenko, O.M., Danylchuk, M.I. Vplyv seredovyshcha ta tekhnolohii utrymannia na produktyvnist svynei [Impact of environment and retention technology on pig productivity]. Naukovi pratsi MDHU [Scientific works of MSU], 2010, no. 119(132), pp. 59-61.

3. Demchuk, M.V., and A.O. Reshetnik. Mikroklimat ta efektyvnist' roboty systemy ventylyatsiyi v rekonstruyovanykh prymishchennyakh dlya svyney $v$ rizni periody roku [Microclimate and efficiency of ventilation system in reconstructed pig rooms at different times of the year]. Nauk. visn. LNAVM. L'viv [Scientific bulletin of LNAVM. Lviv.], 2006, no. 1(28), pp. 36-42.

4. Ericsson, D. Amerykanska tekhnolohiia utrymannia svynei (vid vidluchennia do zaboiu) [American technology for pig retention (from weaning to slaughter)]. Prybutkove svynarstvo [Profitable pig breeding], 2015, no. 3(27), pp. 64-67.

5. Krempa, N.Yu., and M.V., Demchuk. Porivnyal'na dobrobutna otsinka suchasnykh intensyvnykh tekhnolohhiy vyrobnytstva ta system utrymannya tvaryn [Comparative successful evaluation of modern intensive production technologies and animal housing systems]. Naukovyy visnyk LNUVMBT imeni S.Z. Gzhyts'koho [Scientific Bulletin of Lviv National University of Veterinary Medicine and Biotechnology named after S.Z. Gzhytskyi], 2012, no. 3(53), pp. 347-352.

6. Kuznetsov, A.F. Mikroklimat pomeshcheniy i estestvennaya rezistentnost' organizma otkarmlivaemykh sviney $v$ zavisimosti ot sezona goda [Microclimate of premises and natural resistance of the organism of fattening pigs depending on the season of year]. Gigiena promyshlennogo zhivotnovodstva. Novocherkassk [Hygiene of industrial livestock. Novocherkassk], 1978, pp. 140141.

7. Merkureva, E.K. (1977). Geneticheskie osnovy selektsii v skotovodstve [Genetic principles of selection in cattle breeding]. Moscov, Kolos, 240 p.

8. Naydenko, V.K. Sovershenstvovanie tekhnologiy na svinofermakh i svinokompleksakh [Improvement of technologies on pig farms and pig complexes]. Perspektivnoe svinovodstvo: teoriya i praktika [Perspective pig breeding: theory and practice] 2011, no. 2, $6 \mathrm{p}$.

9. Petrushko, A.S., Khodosovskii, D.N., Rudakovskaya, I.I. [and others]. Otkormochnye i myasosal'nye kachestva sviney pri razlichnykh usloviyakh soderzhaniya [Feeding and meat-and-fat qualities of pigs under various conditions of detention]. Visnik agrarnoï nauki Prichornomor'ya [Bulletin of Agrarian Science of the Black Sea region], 2015, no. 2(2), pp. 55-62.

10. Pisarev, Yu.N., and S.A. Serebryakov. Sovremennye sistemy soderzhaniya sviney [Modern pig keeping systems]. Svinovodstvo promyshlennoe i plemennoe [Industrial and pedigree pig breeding], 2008, no. 1, pp. 25-27.

11. Povod, M.H., Kramar, N.I. Vidhodivelni yakosti porosiat na doroshchuvanni zalezhno vid umov yikh utrymannia v rizni periody roku [Feeding qualities of piglets on rearing depending on the conditions of their maintenance in different periods of the year]. Visnyk Sumskoho NAU [Bulletin of Sumy NAU], 2013, no. 7, pp. 173-178.

12. Demchuk, M.V., Reshetnyk, A.O., Banas, T.V., Bohachuk, O.H. Porivnyal'na dobrobutna otsinka suchasnykh intensyvnykh tekhnolohiy vyrobnytstva svyney [Comparative welfare evaluation of modern intensive pig production technologies]. Naukovyy visnyk LNUVMBT im. S.Z. Gzhyts'koho [Scientific Bulletin of Lviv National University of Veterinary Medicine and Biotechnology named after S.Z. Gzhytskyi], 2006, no. 2(29), pp. 48-55.

13. Reshetnyk, A.O., Smolyak, V.V., Layter-Moskalyuk, S.V. Stan dobrobutu svyney u promyslovomu svynarstvi [State of welfare of pigs in industrial pig breeding]. Naukovyy visnyk LNUVMBT im. S. Z. Gzhyts'koho [Scientific Bulletin of Lviv National University of Veterinary Medicine and Biotechnology named after S. Z. Gzhytskyi], 2016, no. 4(72), pp. 66-71.

14. Sabelnikova, Yu.K., Popova, O.A. (2018). Vliyanie sezonov goda na mikroklimat pomeshcheniya dlya sviney [The influence of seasons on the microclimate of premises for pigs]. Molodezhnyy agrarnyy forum 2018: mater. mezhdunar. studencheskoy nauchnoy konferentsii [Youth Agrarian Forum: Mater. Int. student science conference], $199 \mathrm{p}$.

15. Sadomov, N.A. (2015). Growth energy of piglets on rearing, depending on the method of maintenance. Actual problems of the intensive development of animal husbandry. Materialy XVIII Mezhdunar. nauch.-prakt. konf., posvyashchennoy 85-letiyu zooinzhenernogo fakul'teta i 175-letiyu UO «Belorusskaya gosudarstvennaya sel'skokhozyaystvennaya akademiya» [Proc. of the XVIII Intern. scientific-practical conference dedicated to the 85th anniversary of zoo engineering faculty and 175th anniversary of the Belarusian State Agricultural Academy]. Gorki, pp. 163-166.

16. Starodubets, 0.0. Vplyv sezonu roku na vidtvoryuval'ni yakosti svynomatok [Influence of the season on reproductive quality of sows]. Visnyk ahrarnoyi nauky Prychornomorya [Bulletin of Agrarian Science of the Black Sea Region], 2015, no. 42, pp. 100-103.

Вісник Сумського національного аграрного університету 
17. Hammer, K. Soderzhanie sviney s podstilkoy i bez nee [Pig maintenance with and without bedding]. Nemetskoe ptitsevodstvo i svinovodstvo [German poultry and pig farming], 1991, $183 \mathrm{p}$.

18. Chernova, S.E., and V.S., Kazakov. Vliyanie mikroklimata v pomeshchenii na rost, razvitie i otkormochnye kachestva molodnyaka sviney [The influence of indoor microclimate on the growth, development and feeding qualities of young pigs]. Izvestia OGAU [News of Odessa State Agrarian University], 2014, no. 6(50), pp. 127-129.

19. Chernyi, N.V., Onokienko, N.I., Momot, L.N. (2006). Influence of gender on the health of pigs. Ways to intensify the pig industry in the CIS countries. Tez. dokl. XIII mezhdunar. nauch.-prakt. konf. [Thesis. doc. XIII int. scientific-practical conf.]. Zhodino, pp. 162-163.

\section{Ladyka, V.I.,}

Khmelnychyi, L.M.,

Shpetnyi, M.B.,

Vechorka, V.V.

Productivity of piglets on rearing with large-group confinement on polymer and concrete floor

At the article the productivity of piglets on rearing depending on the type of floor at different times of the year was studied. It was found that pigs, which were kept on a more comfortable polymer floor, consumed more than $13.8 \%$ of compound feed in winter, $12.0 \%$ in spring, $8.2 \%$ in summer and $7.7 \%$ in autumn. With large-group retention of piglets in pens with partially slit polymer floor, higher absolute growths were observed in winter - by $18.5 \%$, in spring - by $10.5 \%$, in summer - by $11.0 \%$ and in autumn - by 15.5 $\% \%$. More comfortable conditions of keeping pigs in stalls with polymer floor due to higher intensity of growth of piglets helped to reduce feed costs per unit of growth, in winter - by $4.6 \%$, in spring - by $3.5 \%$, in summer - by $3.1 \%$ and in autumn - by $3.9 \%$. The growth rate of piglets during their rearing season, at all seasons, was higher in stalls with a polymer lattice floor compared to animals raised during this period on a concrete lattice floor. In autumn and winter, the difference in piglet growth in alternative types of flooring increased and decreased in spring and summer season. Feed conversion during the year depended more on the time of year than on the type of lattice in the pens. The safety of piglets was significantly dependent on the type of floor and had significant fluctuations throughout the year in stalls with concrete lattice floor, and the proportion of pigs killed in all seasons was also higher in these pens. On the basic of economically useful traits, the type of lattice floor in the stall for rearing piglets had the greatest influence - further the time of year and even less their interaction. Based on the research, it was found inappropriate to replace in the pens for rearing piglets the polymeric floor on a concrete.

Key words: pigs, rearing, concrete floor, polymer floor, season of year, feed conversion, live weight.

Дата надходження до редакції: 09.02.2019 р. 